\title{
Application of Off-Grid Solar Panels System for Household Electricity Consumptions in Facing Electric Energy Crisis
}

\author{
Selamat Meliala ${ }^{1 *}$, Saifuddin Muhammad Jalil ${ }^{1}$, Wahyu Fuadi², Asran $^{1}$ \\ ${ }^{1}$ Department of Electrical Engineering, Universitas Malikussaleh, Aceh, Indonesia \\ ${ }^{2}$ Department of informatics, Universitas Malikussaleh, Aceh, Indonesia \\ *Corresponding author E-mail: selamat.meliala@unimal.ac.id
}

\begin{abstract}
Manuscript received 30 Oct 2021; revised 10 Nov 2021; accepted 1 Jan 2022. Date of publication 10 Jan 2022

At this time the cost of electricity is very expensive which is felt by the community because the government is still exploring oil and natural gas which is the need for non-renewable energy sources that are running low. This non-renewable energy still dominates for power generation in the thousands of Mega Watts. To anticipate the problem of non-renewable energy that is so big, you can use the On Grid-Tie System, sunlight is converted into DC voltage through the Solar Module, a pure DC voltage that comes out of the solar module. And Off Grid-Tie System namely sunlight is converted into DC voltage through the Solar Module, pure DC voltage generated from the solar module. Then the pure DC voltage uses a DC to DC regulation module or is called a DC regulator. DC regulator which aims to regulate the storage of DC current into the battery. Then the battery is used to supply power to the inverter. The method used in this study uses an off-grid solar home system as a power supply for households that are far from the electricity network or save electricity consumption due to expensive electricity rates. For settings for the intensity of sunlight using a portable holder, the solar panels are shifted manually in order to get the optimal light intensity to produce large output power. In off-grid application testing at household loads, from a load test of 93.5 watts to 750 watts, it shows that the load current is getting bigger and the discharging current is also large so that the duration of using the off-grid system from a load of 93.5 watts is 6 hours long and at a load of 750 watts. up to 15 minutes. This is because the condition of the lead-acid battery is maintained from 13.56 to 11.5 Volt DC, the battery should not be forced below the 11.5 Volt voltage because it will cause damage to the battery. For the use of loads that respond to very high instantaneous currents such as electric irons, dispensers, rice cookers should use more batteries and use an off-grid system voltage higher than 12 Volt DC.
\end{abstract}

\section{Keywords: Off-Grid System, Solar Module, Inverter, Solar Charge Controler, Battery.}

\section{Introduction}

At this time the cost of electricity is very expensive which is felt by the community because the government is still exploring for Oil and Gas which is a non-renewable energy source that is running low. This non-renewable energy still dominates for power generation in the thousands of MegaWatts. To cover the losses from the Unrenewable Energy system, one way is to increase the basic electricity tariff from the large-scale industrial sector, the medium-scale industrial sector, as well as the electricity sector for luxury and simple housing or poor housing. With this increase in electricity payments, it is very detrimental to the community, because they are looking for additional costs for daily use and other problems caused by electricity use.

The government has tried to develop renewable energy technology with several fields in the stage of perfection, namely solar energy (PV), wind turbines, hydropower and hydropower plants, Bio Diesel, Bio Gas, and others. In a Government regulation with an effort to save electrical energy by $20 \%$ (presidential instruction no. 13 of 2011), namely increasing the need for electrical energy for national energy security until 2020 and implementing a national energy management policy target until 2050. However, the supply of electrical power for Unrenewbale Energy is not sufficient for electricity services because it still uses old electrical technology for electricity needs in the industry. And according to the Energy Agency (IEA), it is predicted that power plants or other companies that use Unrenewbale Energy processing technology derived from fuels or the like that produce carbon emissions or gas will stop their power plants by 2050. Renewable energy is currently still using Hydro Power Plants, Micro Hydro Power Plants, Solar panels, or Photo Voltaic which are in vogue with technology that is widely used in housing and small-scale factories are known as Solar Home System (SHS) application technology. This electrical energy does not produce carbon gas emissions at all (pollution) and this is Go Green energy.

The development of electrical energy derived from sunlight has now been widely applied to public housing and this is already known in On-Grid and Off-Grid or Hybrid systems. With the cheap price of solar panels so that people can buy and these have been widely used on walls, portables, and rooftops in households. Household electrical loads used in general are electrical loads that are often used for 
community needs, namely rice cookers, refrigerators, blenders, TVs, air conditioners, water pumps, and others. The use of electrical loads using an off-grid system is widely used because the electrical load still uses AC voltage. With the help of an inverter, the off-grid system can be used to serve loads with sinusoidal voltage [1],[2].

\section{Literature Review}

\subsection{On Grid-Tie System}

On Grid-Tie System, sunlight is converted into DC voltage through the Solar Module, pure DC voltage coming out of the solar module. Then the pure DC voltage is changed in the inverter block to produce AC voltage which is then connected to the PLN power source so that it can supply or provide electrical power. And the AC interconnects voltage source is converted back to DC voltage using a converter so that it produces a pure DC voltage that is used in DC load [3], [4]. The explanation above is shown in Figure 1 and Figure 2.

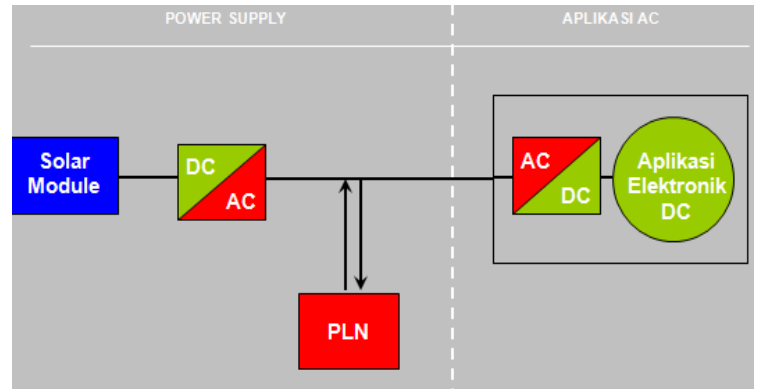

Fig 1. Block Diagram On Grid-Tie System

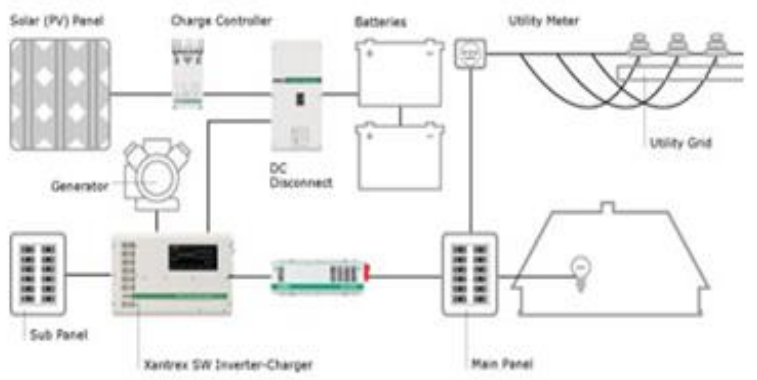

Fig 2. Diagram of On Grid-Tie System and Battery Backup

In Figure 2, as explained in On Grid-Tie, it can be seen that the solar module in addition to supplying DC voltage, also charges the battery to fully charge the current and when night conditions or the PLN source goes out, the battery will function as a DC voltage supplier. Below is Figure 3, the SHS application and the Solar Panel Grid-Tie System in the installation of underprivileged housing or those isolated from the PLN electricity source, and the SHS application for luxury home installations [5].

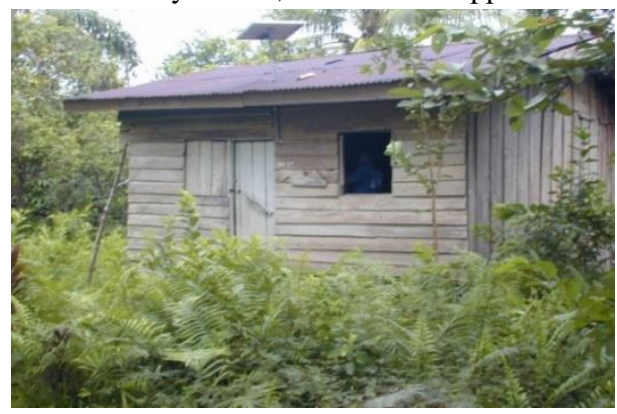

(a) Simple home solar panel application

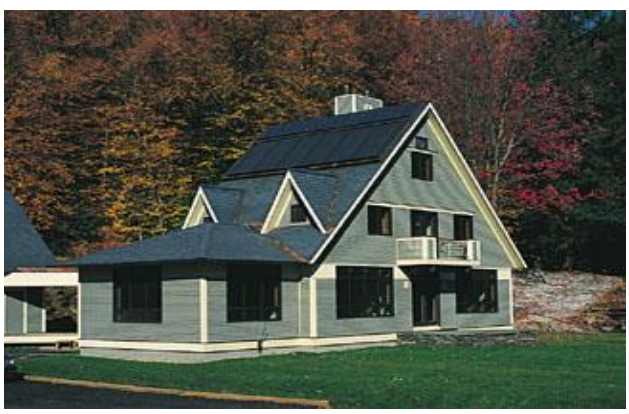

(b) Luxury home solar panel application

Fig 3. Application of Off-Grid Solar Panels Home System

\subsection{Off Grid-Tie System}

In the Off Grid-Tie System, sunlight is converted into DC voltage through the Solar Module, a pure DC voltage that comes out of the solar module. Then the pure DC voltage uses a DC to DC regulation module or is called a DC regulator. DC regulator aims to regulate the storage of DC into the battery [6]. Then the output voltage from the DC regulator is converted to AC voltage using an inverter to produce a sinusoidal voltage. From the output of the AC inverter voltage is rectified using a rectifier or called a converter. So that the DC load can feel the pure DC wave voltage. Other sources of electricity originating from PLN are not connected, but the DC source used comes from the battery [7],[8],[9]. The explanation above is shown in Figure 4. 


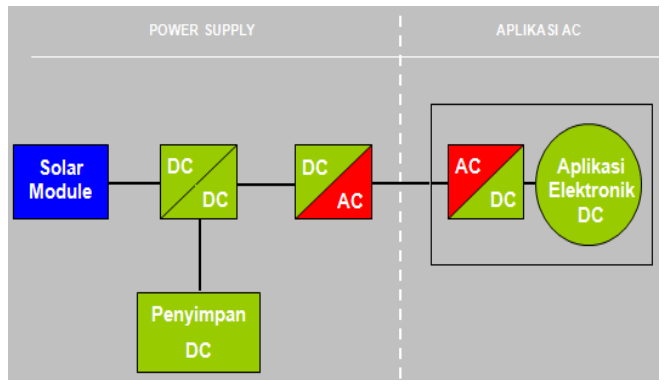

Fig 4. Off Grid-Tie System Block

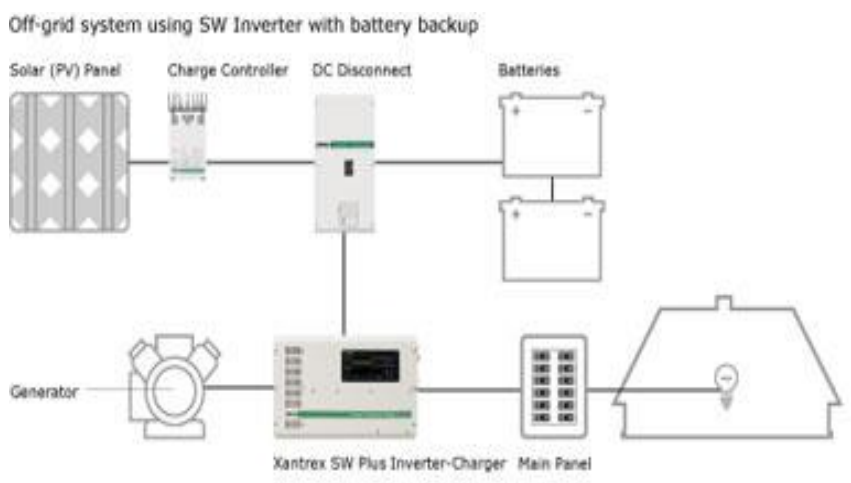

Fig 5. Diagram of Off Grid-Tie System with battery and generator

\subsection{Inverter}

The general definition of an inverter is a power electronic device that functions to convert direct voltage (DC) into alternating voltage (AC) [10]. There are two types of inverters, namely voltage source inverter (VSI) and current source inverter (CSI). VSI inverter [11] as shown in Figure 6 below.

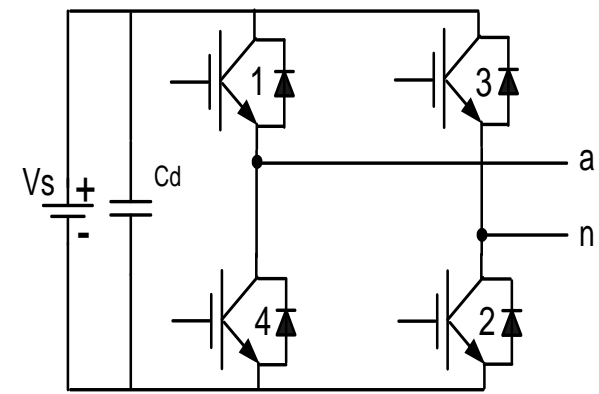

Fig 6. Inverter VSI (Voltage Source Inverter)

The CSI inverter on the dc bus is equipped with an inductance as shown in Figure 7.

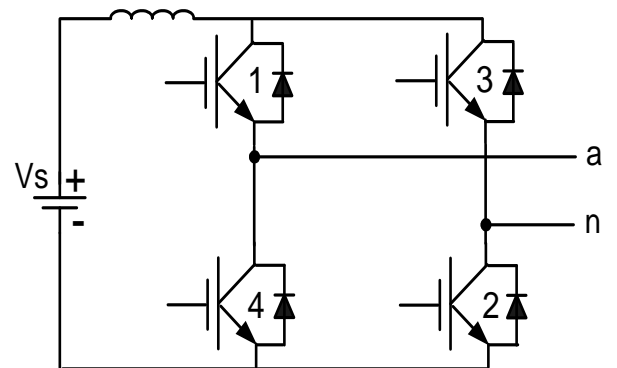

Fig 7. CSI Inverter (Current Source Inverter)

\subsection{Calculation of household load power for Off-Grid System}

Calculating the power of solar panels and batteries used in the Off-Grid System, use the equation below 1.

$$
\sum P=\left(\frac{T E}{C P \times P S H}\right)
$$


Where :

$\mathrm{P} \quad=$ Number of panels used

TE $\quad=$ Total electricity consumption (Watthour)

$\mathrm{CP} \quad=$ Solar panel capacity (WP)

$\mathrm{PSH}=$ Peak Sun Hours / optimal length of time in the sun (hours)

The amount of PSH depends on how long the optimal sunlight hits the surface of the solar panel in a day. Generally, PSH is around 4 or up to 5 hours depending on cloudy conditions that cover the sun's rays (shading). Usually, the shading conditions cause the PSH of light to decrease in time, the time depends on the length of shading in hours. Below is the Peak Sun Hours (PSH) per day [12], [13] shown in Figures 8 a and $8 \mathrm{~b}$.

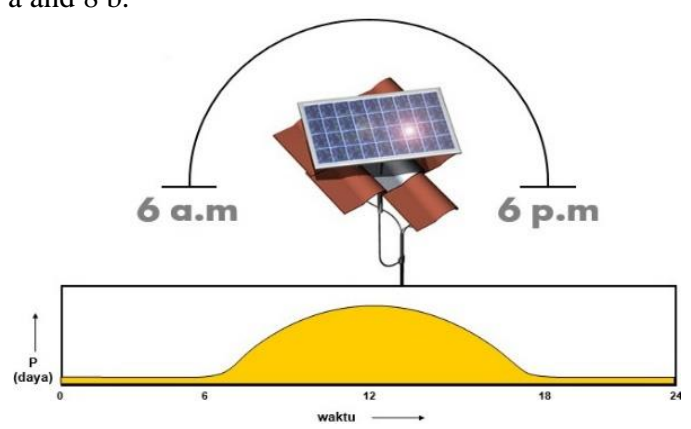

(a) Sunny weather conditions

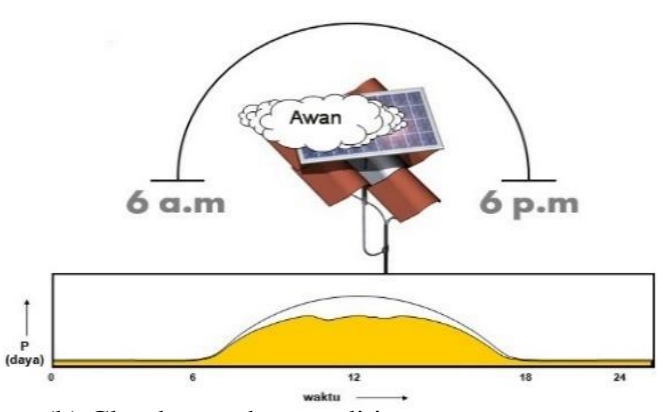

(b) Cloudy weather conditions

Fig 8. PSH weather conditions affecting solar panels

And to determine the need for battery capacity in the Off-Grid System design [14] as follows :

$$
\sum B=\left(\frac{T E}{C B \times D O D}\right) \times A D
$$

Where :

$\mathrm{B}=$ Number of batteries used

$\mathrm{TE}=$ Total electricity consumption (Watthour)

$\mathrm{CB}=$ Battery Capacity $(\mathrm{WH})$

DOD = Depth of Discharge / Percentage of battery discharge (\%), usually 50\% for VRLA battery type

$\mathrm{AD}=$ Autonomy days / battery usage time (days)

\subsection{Battery}

Batteries in the design of solar panels are needed to back up and store the charging current from the solar panels. There are many types of batteries, namely Lead Acid, Lithium Ion, Nickel Cadmium, Nickel Metal Hybrid. Battery specifications are needed for storage power and the duration of battery use when operated using an electrical load [15],[16]. Below are the characteristics of the discharge current and the area of the length of time a battery with a capacity of $100 \mathrm{WH}$ and a voltage of 12 volts [17], [18],[19],[20] is shown in Figures 9 and 10 .

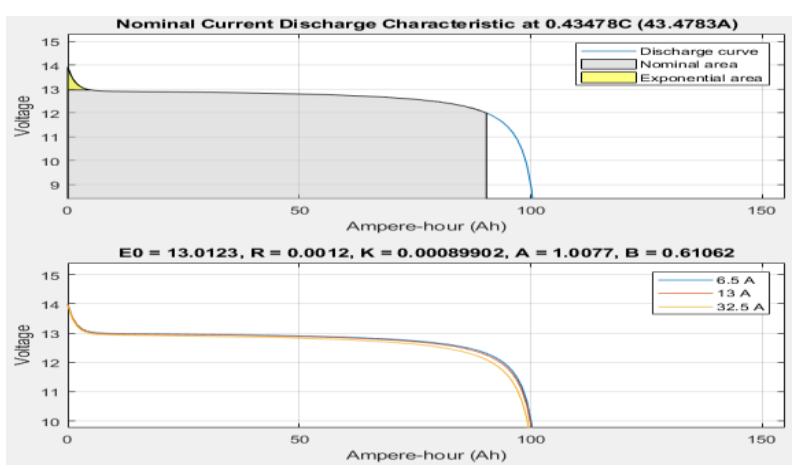

Fig 9. Discharge Characteristics Nominal Current of a 100 AH Lead Acid Battery

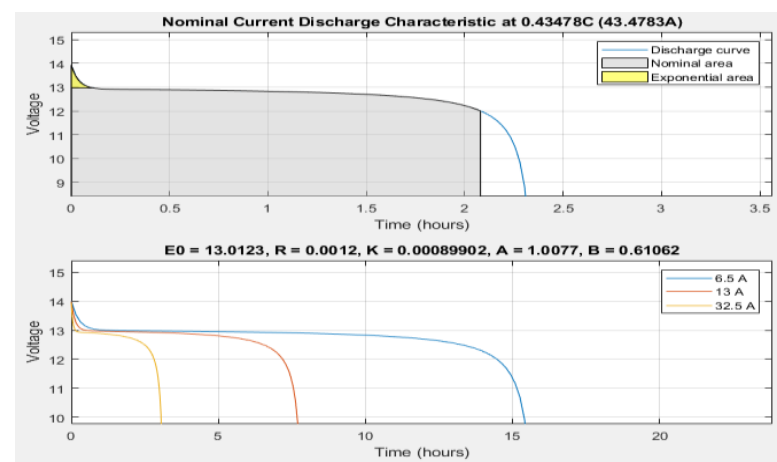

Fig 10. Discharge Time Characteristics Nominal Current of 100 AH Lead Acid Battery 


\section{Methods}

This research belongs to the quantitative type using primary data, namely data from interviews and direct observations with the PLN and the people of Gampong Paloh Lada Krueng Geukueh, and distributing questionnaires to the people of Gampong Paloh Lada. For determining AC load capacity by adjusting the load capacity of $4 \mathrm{~A}$, installing $\mathrm{AC}$ voltage and the type of load used daily.

\subsection{Research sites}

In this study, the location of the household is in Gampong Paloh Lada Krueng Geukueh, Aceh Province, which is close to rice fields. This research will apply solar panels to one of the houses in BTN Arun Paloh Lada.

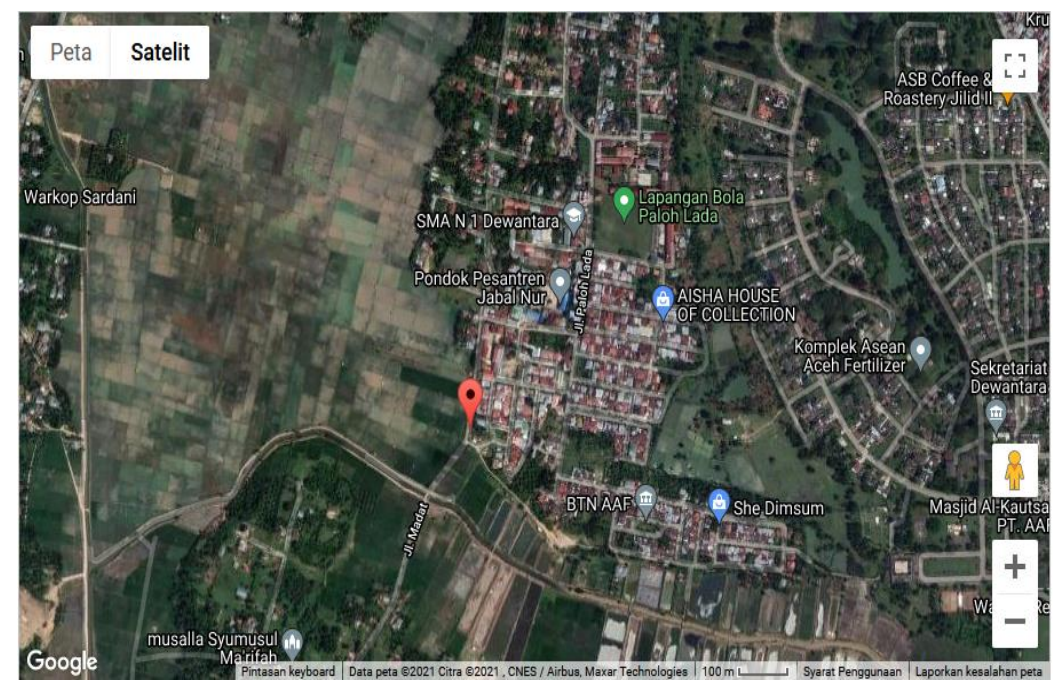

Fig 11. Research site

\subsection{Research Design}

To make it easier to find out the research design in this study, the following research design framework is presented:

1. Data collection includes literature study methods, observation methods, interview methods, distributing questionnaires to the public to find out the types of household burdens that are often used, and then the data will be sorted according to the object of research.

2. Make a schematic diagram of the hardware research design.

3. Make a portable solar panel holder to get optimal intensity.

4. Make a prototype based on the results of the research design to be carried out which is shown in Figure 12.

5. Adjust the portable solar panel holder to get the optimal point of sunlight.

6. After installing all the research designs, measurements are made on the voltage and current of the solar panel, on the battery voltage and battery current, as well as the output voltage and current on the inverter that is connected to the AC Grid.

7. Measurement for the Off-Grid System voltage test using a DC ampere pliers and AVO meter.

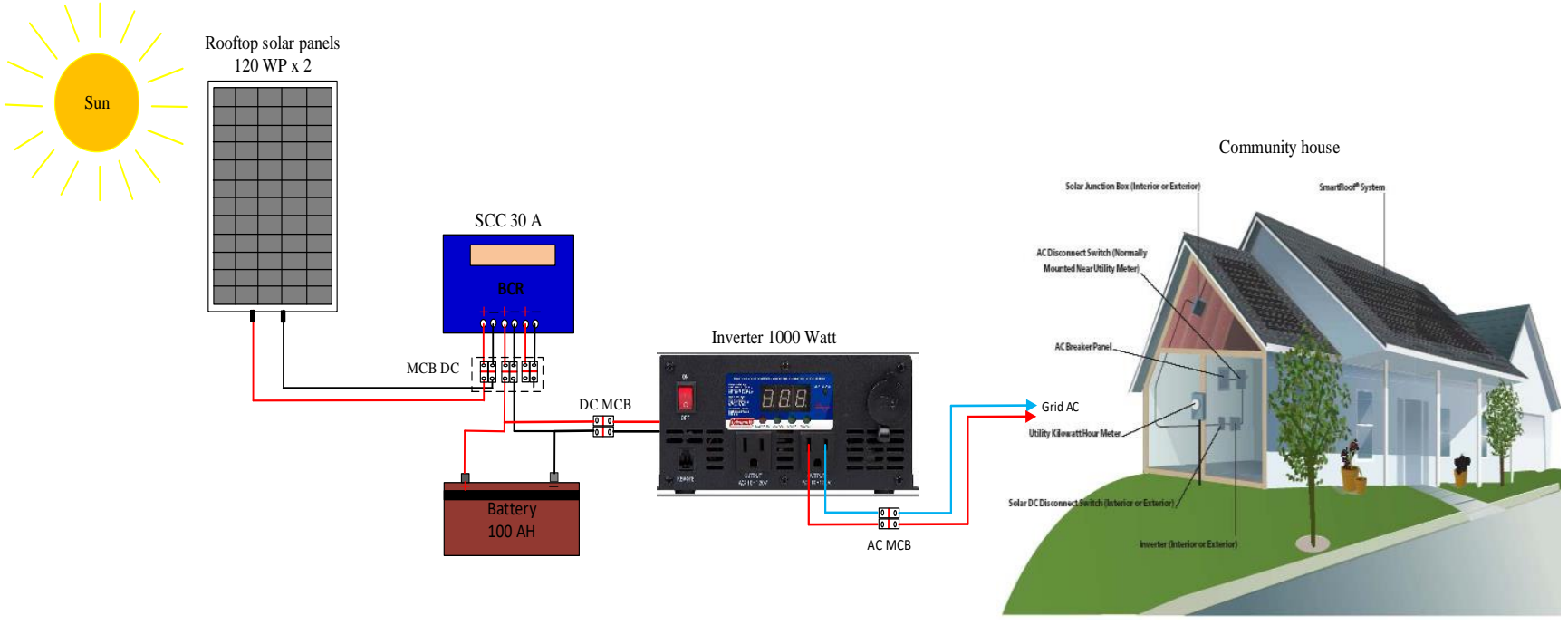

Fig 12. Research Design Diagram

Data on the type of load used were obtained from electricity customers by dividing questionnaires and interviewing the village community so that data on the types of electrical loads that were commonly used were obtained from all simple and underprivileged household electricity customers, including the following: 
Table 1. Total household load used

\begin{tabular}{clccc}
\hline No & Load Type & $\begin{array}{c}\text { @ Load Power } \\
\text { (Watt) }\end{array}$ & Total Load & $\begin{array}{c}\text { Total Load Power } \\
\text { (Watt) }\end{array}$ \\
\hline 1 & LED lamp & 5 & 3 & 15 \\
\hline 2 & LED lamp & 10 & 5 & 50 \\
\hline 3 & TV & 90 & 1 & 90 \\
\hline 4 & Rice Cooker & 300 & 1 & 300 \\
\hline 5 & Electric Iron & 400 & 1 & 400 \\
\hline 6 & Fan & 60 & 1 & 60 \\
\hline 7 & Dispenser & 300 & 1 & 300 \\
\hline & & & Total load power & 1215 \\
\hline
\end{tabular}

\subsection{Off-Grid System Specification}

The specifications for the prototype design of the off-grid system for the application of solar panels in households with a load of 4 A are shown in Table 2

Table 2. Off Grid System Specifications

\begin{tabular}{|c|c|c|}
\hline No & Description & Specifications \\
\hline 1 & Solar charge controller & $30 \mathrm{~A}$ \\
\hline 2 & Solar module & $240 \mathrm{WP}$ \\
\hline 3 & Battery & $100 \mathrm{Ah}$ \\
\hline 4 & DC MCB & $10 \mathrm{~A}, 20 \mathrm{~A}, 63 \mathrm{~A}$ \\
\hline 5 & $\mathrm{MCB} A C$ & $4 \mathrm{~A}$ \\
\hline 6 & Inverter & $1000 \mathrm{Watt}$ \\
\hline 7 & Fuse Holder and fuse & $10 \mathrm{~A}, 20 \mathrm{~A}, 25 \mathrm{~A}$ \\
\hline 8 & Cable $4 \mathrm{~mm}^{2}$ & $16 \mathrm{~m}$ \\
\hline 9 & Cable $10 \mathrm{~mm}^{2}$ & $2 \mathrm{~m}$ \\
\hline 10 & Cable $16 \mathrm{~mm}^{2}$ & $3 \mathrm{~m}$ \\
\hline 11 & MC4 parallel connector & 2 set \\
\hline 12 & MC4 male, female connector & 4 set \\
\hline
\end{tabular}

\section{Result and Discusion}

In the application of off-grid solar panels, the design system is based on Figure 12 where the Solar Charge Controller (SCC) is used using the PWM system. This PWM SCC regulates the maximum voltage and current regulation on a 12 Volt DC system and 30 Amperes DC. This off-grid regulation system is the voltage of the solar panel in an open-circuit voltage of 22 Volts with no load and the battery after the battery is installed and the system voltage becomes 12 Volt DC. When the battery voltage drops to 11 Volt DC, the SCC charges the battery for charging the battery current so that the battery voltage is higher than 12 volts -14 volts. Solar panels with a capacity of 240 WP work with a higher voltage than the battery voltage.

During the optimal duration of the solar panel, 5 hours per day, the solar panel will always charge the battery if the battery has been set to DOD (Depth of Discharge) settings. When the battery condition is full, the battery is used to drive the inverter, namely the 12 V DC voltage is converted to 220 Volt AC voltage which can be supplied to household loads with a capacity of 1000 Watts.

The load used is in the form of a load of a dispenser, iron, rice cooker, TV lamp. The load must be regulated under conditions that cannot jump very high such as irons, dispensers, electric pump motors because the inverter uses a high-frequency type inverter. To regulate the inrush current, the iron is set at a hot temperature. Likewise with the load of the water pump motor, dispenser, and CRT TV. Below is Figure 13 the application of the off-grid system in households.

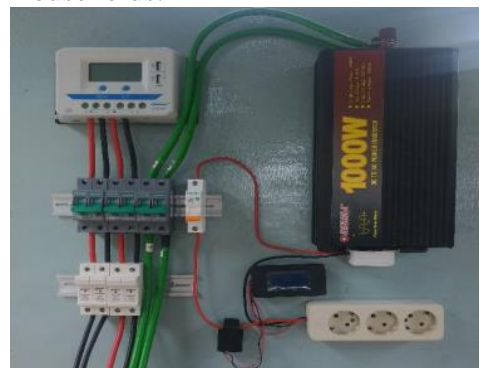

Fig 13. Off-Grid System Device

\subsection{Testing on Off-Grid system}

Testing this off-grid system to find out how long the battery charger uses SCC before using the inverter to serve AC loads. Testing with the condition of the battery voltage $80 \%$ of the condition of the battery charger is usually 11.5 Volt DC from 13.5 Volt. For the off-grid system the data was measured for 7 days and the voltage with the average optimal value taken for the battery charger is tabulated in Table 3 below. 
Table 3. Charge Battery on off grid system

\begin{tabular}{cccccc}
\hline No & Duration Time & $\begin{array}{c}\text { Weather } \\
\text { Conditions }\end{array}$ & $\begin{array}{c}\text { Solar panel surface } \\
\text { temperature }\left({ }^{\circ} \mathrm{C}\right)\end{array}$ & $\begin{array}{c}\text { Charging } \\
\text { Current }(\mathrm{ADC})\end{array}$ & $\begin{array}{c}\text { Charging } \\
\text { Voltage }\left(\mathrm{V}_{\mathrm{DC}}\right)\end{array}$ \\
\hline 1 & $9.00-10.00$ & Hot & 52,5 & 3,1 & 13 \\
\hline 2 & $10.00-11.00$ & Hot & 53 & 6,9 & 13,68 \\
\hline 3 & $11.00-12.00$ & Scorching hot & 59,4 & 2,2 & 13,4 \\
\hline 4 & $12.00-13.00$ & Scorching hot & 58,7 & 0,7 & 13,2 \\
\hline 5 & $13.00-14.00$ & Scorching hot & 57,4 & 0,8 & 13,43 \\
\hline 6 & $14.00-15.00$ & Hot & 52,4 & 0,2 & 13,45 \\
\hline 7 & $15.00-16.00$ & Hot & 4,2 & 0,2 & 13,1 \\
\hline
\end{tabular}

\subsection{Off-Grid system testing using inverter}

Testing the off-grid system using an inverter, namely where the battery condition is full of batteries on the 13.5 off-grid system. then by using an inverter it is recorded how much AC current is used during the use of household electricity loads which are regulated according to variations in conditions from low to high and how long each load is used in the off-grid system. And the AC current used in each of these household loads is shown in Table 4 below.

Table 4 Voltage, current and output power of Inverter on Off-Grid System

\begin{tabular}{ccccc}
\hline No & $\begin{array}{c}\text { Load Power } \\
\text { (Watts) }\end{array}$ & $\begin{array}{c}\text { Duration of use } \\
\text { (Hours) }\end{array}$ & Load Current (IAcrms) & $\begin{array}{c}\text { Voltage } \\
\text { (VAcrms) }\end{array}$ \\
\hline 1 & 93,5 & 5 & 0,419 & 225 \\
\hline 2 & 194 & 3 & 0,76 & 223 \\
\hline 3 & 375 & 2 & 1,7 & 221 \\
\hline 4 & 542 & 1 & 2,52 & 220 \\
\hline 5 & 750 & 0,3 & 3,4 & 220 \\
\hline
\end{tabular}

Based on Table 4 the duration of the use of household loads and the current generated on the off-grid system, the greater the power consumption of household electricity, the more sloping while the curve of the electric load and current generated is the greater the load power and is used at 800 Watt power with 1000 Watt inverter capability with this type of high frequency inverter so that it cannot serve such high instantaneous load currents as shown in Figure 4.2 and Figure 4.3.

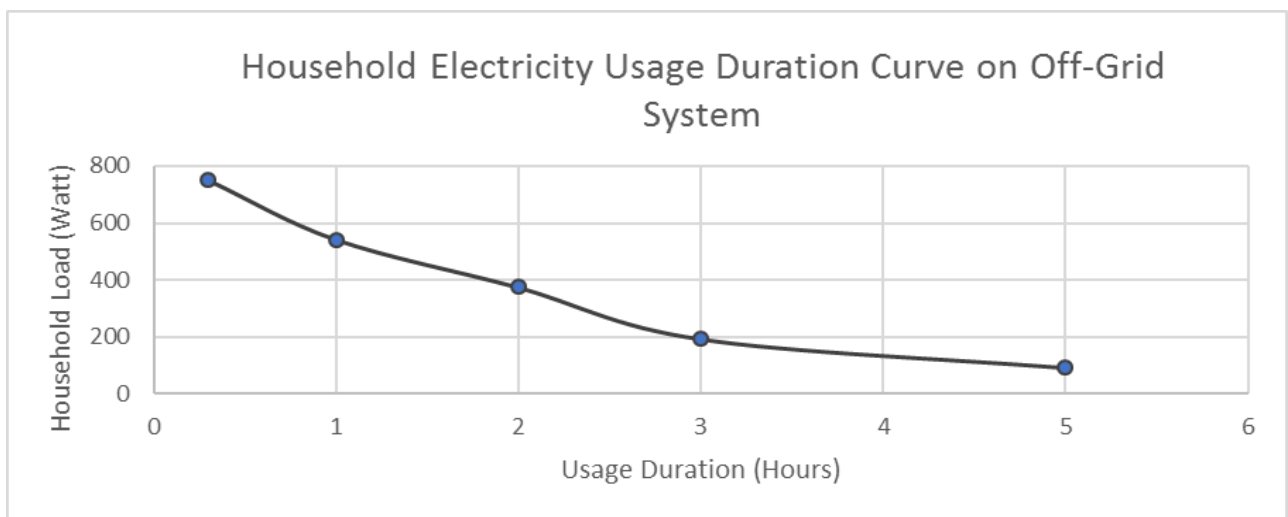

Fig 14. Duration curve of household electricity consumption off grid system

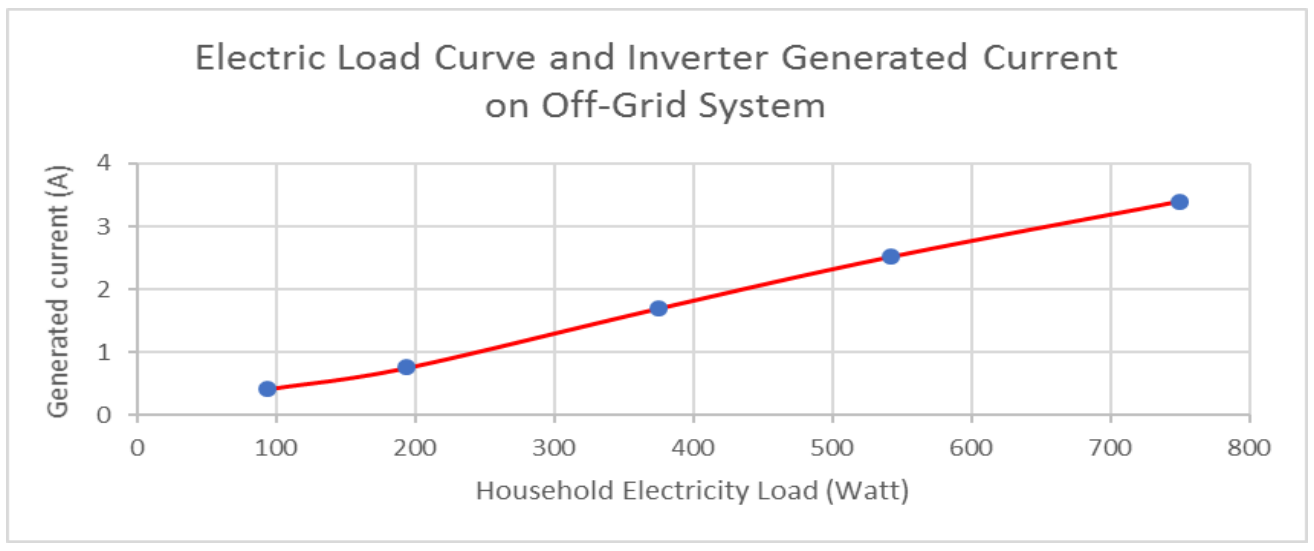

Fig 15. Electric load curve and current generated by the inverter off-grid system 


\section{Conclusion}

Based on the results of data from testing the application of the off-grid system in households, it can be concluded: 1 . The large capacity of the solar panel affects the working system of the off-grid system in terms of the battery charging process and the work of the inverter, the greater the household load, the faster the duration of battery usage.

2. For the use of large household loads must be adapted to a lot of battery capacity.

3. For 12 Volt DC input voltage on the inverter is very small because when serving loads with high instantaneous current surges such as dispensers, irons, and electric stoves there will be a high battery voltage drop on the off-grid system.

\section{Acknowledgment}

I would like to thank the management of the Unimal research grant assistance (ADB) who has assisted in the research process with the title Application of Off-Grid System Solar Panels for Household Electricity Needs in Facing the Electrical Energy Crisis. The research still has shortcomings and the author still hopes for improvements from the readers to improve this paper.

\section{References}

[1] S. Meliala, "Implementasi On Grid Inverter pada Instalasi Rumah Tangga untuk Masyarakat Pedesaan dalam Rangka Antisipasi Krisis Energi Listrik," Jurnal Litek: Jurnal Listrik Telekomunikasi Elektronika, vol. 17, no. 2. p. 47, 2020, doi: 10.30811/litek.v17i2.1902.

[2] X. Y. Guo, J. M. Chen, and Q. H. Liu, "Real-time and grid-connected control of PV power system," APAP 2011 - Proc. 2011 Int. Conf. Adv. Power Syst. Autom. Prot., vol. 2, pp. 923-928, 2011, doi: 10.1109/APAP.2011.6180724.

[3] S. Meliala, R. Putri, and M. Sadli, "Perancangan Penggunan Panel Surya Kapasitas 200 WP On Grid System pada Rumah Tangga di Pedesaan," J. Tek. Elektro Univ. Malikussaleh, vol. 5, no. 3, pp. 100-111, 2020.

[4] J. Tompkins, M. Musiak, and N. Magotra, "Design of a low cost DC/AC inverter for integration of renewable energy sources into the smart grid," Midwest Symp. Circuits Syst., vol. 2017-Augus, pp. 487-490, 2017, doi: 10.1109/MWSCAS.2017.8052966.

[5] G. E. Wkh et al., "Control of Low Volatge Grid-Tied solar PV System," pp. 5-10.

[6] A. Malkhandi, S. Mishra, and N. Senroy, "The control loop shaping in grid tied inverter for weak grid scenario," 202021 st Natl. Power Syst. Conf. NPSC 2020, 2020, doi: 10.1109/NPSC49263.2020.9331894.

[7] A. Jasuan, Z. Nawawi, and H. Samaulah, "Comparative Analysis of Applications Off-Grid PV System and On-Grid PV System for Households in Indonesia," Proc. 2018 Int. Conf. Electr. Eng. Comput. Sci. ICECOS 2018, pp. 253-258, 2019, doi: 10.1109/ICECOS.2018.8605263.

[8] A. Shahid, "Smart Grid Integration of Renewable Energy Systems," 7th Int. IEEE Conf. Renew. Energy Res. Appl. ICRERA 2018, vol. 5, no. Ii, pp. 944-948, 2018, doi: 10.1109/ICRERA.2018.8566827.

[9] G. Wu et al., "Parameter Design Oriented Analysis of the Current Control Stability of the Weak-Grid-Tied VSC," IEEE Trans. Power Deliv., vol. 36, no. 3, pp. 1458-1470, 2021, doi: 10.1109/TPWRD.2020.3009517.

[10] M. Bouzguenda, A. Gastli, A. H. A. Badi, and T. Salmi, "Solar photovoltaic inverter requirements for smart grid applications," 2011 IEEE PES Conf. Innov. Smart Grid Technol. - Middle East, ISGT Middle East 2011, vol. 2010, pp. 1-5, 2011, doi: 10.1109/ISGT-MidEast.2011.6220799.

[11] L. Yang et al., "A new theory of reactive power control of grid connected PV inverter," Proc. - 2015 Int. Conf. Intell. Transp. Big Data Smart City, ICITBS 2015, pp. 35-38, 2016, doi: 10.1109/ICITBS.2015.15.

[12] J. Mnisi, S. P. D. Chowdhury, and L. Ngoma, "Grid integration of solar PV for green energy," 6th IEEE Int. Energy Conf. ENERGYCon 2020, pp. 782-786, 2020, doi: 10.1109/ENERGYCon48941.2020.9236485.

[13] V. Myathari, S. Siddiki, and M. Siddiki, "Design and Economic analysis of a Grid-tied PV system to power a small village," pp. 1658-1664, 2020.

[14] J. B. Noshahr, B. Mohamadi, M. Kermani, and M. Kermani, "Operational Planning of Inverter Control in a grid connected Microgrid with hybrid PV and BESS," Proc. - 2020 IEEE Int. Conf. Environ. Electr. Eng. 2020 IEEE Ind. Commer. Power Syst. Eur. EEEIC / I CPS Eur. 2020, 2020, doi: 10.1109/EEEIC/ICPSEurope49358.2020.9160692.

[15] S. Batteries Committee of the IEEE Power and E. Society, "IEEE Recommended Practice for Maintenance, Testing, and Replacement of Vented Lead-Acid Batteries for Stationary Applications IEEE Power \& Energy Society," vol. $2014,2011$.

[16] The Institute of Electrical and Electronics Engineers - IEEE, "IEEE Recommended Practice for Installation and Maintenance of Lead-Acid Batteries for Photovoltaic ( PV ) Systems," Std 937-2007, IEEE, vol. 2007, no. June, pp. 1-31, 2007.

[17] D. Mohapatra, S. Padhee, and J. Jena, "Design of Solar Powered Battery Charger: An Experimental Verification," 2018 IEEE Int. Students' Conf. Electr. Electron. Comput. Sci. SCEECS 2018, 2018, doi: 10.1109/SCEECS.2018.8546929.

[18] M. Alramlawi, Y. Souidi, and P. Li, "Optimal design of PV-Battery Microgrid Incorporating Lead-acid Battery Aging Model," Proc. - 2019 IEEE Int. Conf. Environ. Electr. Eng. 2019 IEEE Ind. Commer. Power Syst. Eur. EEEIC/I CPS Eur. 2019, 2019, doi: 10.1109/EEEIC.2019.8783927.

[19] M. I. Wahyuddin, P. S. Priambodo, and H. Sudibyo, "State of Charge (SoC) Analysis and Modeling Battery Discharging Parameters," Proc. - 2018 4th Int. Conf. Sci. Technol. ICST 2018, pp. 2-6, 2018, doi: 10.1109/ICSTC.2018.8528631.

[20] J. Zich and J. Jandik, “Active battery management system for home battery energy storage," Proc. - 2020 21st Int. Sci. Conf. Electr. Power Eng. EPE 2020, pp. 18-21, 2020, doi: 10.1109/EPE51172.2020.9269172. 